\title{
Spor Seyircileri için Dışsal ve İçsel Güdü Ölçekleri Kısa Versiyon Uyarlaması ve Çok Değişkenli İlişskisel Bir Uygulama*
}

\author{
Ercan POLAT ${ }^{1 \dagger}$ (D), Hasan Birol YALÇIN ${ }^{2}$ iD \\ ${ }^{1}$ Ağrı İbrahim Çeçen Üniversitesi, Ağrı. \\ ${ }^{2}$ Bolu Abant İzzet Baysal Üniversitesi, Bolu.
}

Orijinal Makale

Gönderi Tarihi: 29.05.2020
Kabul Tarihi: 27.06.2020
DOI: $10.25307 /$ jssr.744732

Online Yayın Tarihi: 30.06 .2020

\section{Öz}

Bu çalışmada, daha kısa ve kullanışlı olması için Spor Seyircileri İçin Dışsal Güdü Ölçeği (SSİDGÖ) ile Spor Seyircileri İçin İçsel Güdü Ölçeği'ne (SSIİGÖ) Doğrulayıcı Faktör Analizi (DFA) uygulanması ve bunun yanısıra ilişkilerin kanonik korelasyon analizi yöntemiyle incelenmesi amaçlanmıştır. İlişkisel tarama modeli uygulanarak gerçekleştirilen araştırmanın çalışma grubunu, spor müsabakalarını seyreden ve bir üniversitenin farklı bölümlerde okuyan 310 gönüllü öğrenciler oluşmuştur. Çalışmada veri toplama aracı olarak Polat ve Yalçın (2014) tarafindan geliştirilmiş olan, Spor Seyircileri İçin Dışsal Güdü Ölçeği (SSIDGÖ) ve Spor Seyircileri İçin İçsel Güdü Ölçeği (SSIIIGÖ) kullanılmıştır. Geliştirilen ölçeklerin model yapısını test etmek amacıyla birinci düzey DFA ve sonrasında ise güvenilirlik analizleri yapılmıştır. Bu analizler için LISREL ve SPSS paket programı kullanılmıştır. Ayrıca NCSS istatistik programı kullanılarak ölçekler arası çoklu ilișkileri belirlemek amacıyla Kanonik Korelasyon analizi yapılmıştır. İki ölçek için de ilk yapılan DFA analizlerine göre; SSİDGÖ için 9 alt boyutlu yapı korunmuş, 34 olan madde sayısı ise 25'e düşürülmüştür. SSİIGÖ için ise yine 7 alt boyut değişmezken 40 maddeli ölçek 21'e düşürülmüştür. Kanonik korelasyon sonuçları incelendiğinde ilk dört değişken çiftinin anlamlı olduğu bulunmuştur. Anlamlı ilk iki değișken çiftine göre dışsal seyretme güdülerinden oluşan bağımsız değişkenlerin içsel seyretme güdülerinden oluşan bağımlı değişkenleri \%71 oranında açıkladığı belirlenmiştir. İlk değişken çiftinde ise dışsal güdülerden Oyun Bilgisi boyutu, içsel güdülerden ise Beceri Düzeyi boyutu en çok ilişkisel katkıyı yapmıştır. Bu sonuca göre, seyircilerin spora ilişkin bilgi düzeyinin ve sporcuların yansıttığı sportif becerilerin diğer güdülerin gelişim ve etkileşiminde daha önemli etkilerinin olduğu söylenebilir.

Anahtar kelimeler: Spor seyircisi, İçsel güdü, Dışsal güdü, Geçerlik, Güvenirlik, Kanonik korelasyon.

\section{Short Version Adaptation of External and Internal Motivation Scales for Sport Spectators and A Multi Variable Relationship Implementation}

\begin{abstract}
In this study, in order to be shorter and more useful, it is aimed to apply confirmatory factor analysis to the External Motivations Scale for Sport Spectators (EMSSS) and the Internal Motivations Scale For Sport Spectators (IMSSS) as well as to analyze the relations with canonical correlation analysis method. The study group of the research carried out by applying the relational screening model consisted of 310 volunteer students watching sports competitions and studying in different departments of a university. In the study, the External Motivations Scale For Sport Spectators (EMSSS) and the Internal Motivations Scale For Sport Spectators (IMSSS) developed by Polat and Yalçın (2014) were used as data collection tools. In order to test the model structure of the developed scales, first level Confirmatory Factor Analysis (CFA) and then reliability analyzes were performed. LISREL and SPSS software were used for these analyzes. In addition, Canonical Correlation analysis was performed to determine multiple relationships between scales using NCSS statistics program. According to the initial DFA analysis for both scales; 9 sub-dimensional structures were preserved for EMSSS, and the number of items from 34 was reduced to 25. For IMSSS, while 7 sub-dimensions did not change, the 40-item scale was reduced to 21 . When the canonical correlation results are examined, it is found that the first four variable pairs are significant. According to the meaningful first two pairs of variables, independent variables consisting of external watching motives explained $71 \%$ of the dependent variables consisting of internal watching motives. In the first pair of variables, the Game Knowledge dimension from the external motives and the Skill Level dimension from the internal motives made the most relational contribution. According to this result, it can be said that the knowledge level of the spectators and the sports skills reflected by the athletes have more important effects on the development and interaction of other motives.
\end{abstract}

Key Words: Sports spectator, Internal motive, External motive, Validity, Reliability, Canonical correlation.

\footnotetext{
* Bu çalışmanın bir bölümü Uluslararası Balkan Spor Bilimleri Kongresinde (Mayıs, 2017) sözel bildiri olarak sunulmuştur. †Sorumlu yazar: Doç.Dr. Ercan POLAT, E-posta: ercihanpolat@hotmail.com.
} 
Polat, E. ve Yalçın, H.B. (2020). Spor seyircileri için dışsal ve içsel güdü ölçekleri kısa versiyon uyarlaması ve çok değişkenli ilişkisel bir uyarlama. Spor Bilimleri Araşstırmaları Dergisi, 5(1), 111-129.

\section{GíRiş}

Toplumsal ilerleme, ulaşım, teknoloji ve iletişim sektöründeki gelişmelerin yanı sıra globalleşme spor olgusunu dünyanın en önemli endüstrilerinden biri olmasını sağlamıştır. Bu endüstrinin en lokomotifi ise spor seyircileridir. Seyirci ve taraftar olarak ayrı ayrı tanımlanan bu grup tüketiciler performans sporuna karsı pozitif ilgi sahibidirler ve dolayısıyla sporu ya televizyondan, internetten ve diğer medya iletişim araçlarından takip ederler ya da canlı olarak yerinde seyretme eğilimindedirler (Schwarz ve Hunter, 2008: 106; Smith, 2008: 34). Spor seyircilerinin tüketim alışkanlıklarının nasıl şekillendiğini ve satın alma kararlarında etkili faktörlerin ne olduğunu tespit etmek ise bu endüstrinin daha iyi anlaşılmasına ve gelişmesine olumlu yönde katkıda bulunacaktır.

Bireyi tüketim kararına yönelten faktörlerden bir tanesine güdülenmedir. Tüketicinin davranışlarını açıklamada önemli bir kavram olan güdülenme, bireyi ihtiyaç ve istekler doğrultusunda bir şeyi yapmak için oluşan isteklilik ve bu istekliliği tatmin etmek için ortaya konan çabaların tümü olarak ifade edilmektedir (Eren, 2015: 498; Robbins, 1992: 45; Schwarz ve Hunter, 2008: 94-108). Güdülemenin çeşitli sinıflandırmaları olmakla beraber, içten ya da dıştan gelen şiddetli veya yoğun bir uyarıcının etkisiyle ve istekle oluşturulan bir davranış durumuna da işaret ettiği belirtilmektedir (Kast ve Rosenzweig, 1985; Silah, 2000). İ̧̧ten gelen uyarıcılar dediğimiz içsel güdüler kişinin kendi iç dünyasından gelen ilgi, araştırma ve keşfetme eğilimidir (Gray ve Starke, 1988:105-106; Ryan, 1995). Dışsal güdüler ise kişinin doğrudan kendi iç dünyasından kaynaklanmayan ancak çevresel şartlardan etkilenip şekillenen ve o kişi için itici bir güce sahip olan uyarıcılardır (Gray ve Starke, 1988:105-106; Ryan ve Deci, 2000). Spor tüketicisi açısından değerlendirildiğinde güdülenme, insanların spor tüketicisi olarak davranmalarına sebep olan süreçler olarak ifade edilmektedir (Funk, 2008: 16).

Sporda tüketici güdüleri karmaşı olasına karşın spor pazarına ilişkin bu güncel konunun araştırılması önemlidir. Spor pazarlama alanındaki araştırmacıların tüketicilerin sporla ilgili ürünleri ve hizmetleri satın alırken nasıl ve ne düzeyde güdülendiklerini anlamaya ihtiyaçları vardır (Smith, 2008: 35). Özellikle uluslararası boyutta yapılan çalışmalarda; aile, bağlılık, başarı, beceri, bilgi, drama, eğlence, kaçış, estetik, heyecan, kültür ve sosyal ilişki gibi birçok boyuttan oluşan tüketim güdülerine yer verilmiş̧ir. Ortaya çıkan bu boyutların ise sporu "neden seyrederiz?" sorusuna ilişkin problemi açıklamaya çalıştığı görülmektedir (Funk, 2008; Mullin, Hardy ve Sutton, 2007; Shank, 2005; Smith, 2008; Schwarz ve Hunter, 2008: 94).

Sporu seyretme güdülerinin doğru anlaşılması halinde, gerçekleştirilen spor organizasyonlarına yönelik spor pazarlamacılarının ortaya koyduğu tutundurma çabalarının, etkili bir şekilde gerçekleştirilmesi kolaylaşacaktır. Böyle bir durumda oluşacak ilgiden dolayı sporun seyredilme oranları da artacaktır (James ve Ross, 2004). Özellikle Türkiye'de genel anlamda sporun seyredilme oranlarının oldukça düşük olduğu ve pek çok spor branşına toplumsal ilginin çok yetersiz olduğu söylenebilir. Nitekim Türkiye İstatistik Kurumu tarafından 2007 yllında yapılan ve ülke geneline uyarlanan bir araştırmada, 15 ve daha yukarı yaştaki nüfusun sadece $\% 4,5$ 'in seyirci olarak spor faaliyetlerine katıldığı belirtilmiştir (TUiK, 2008: 62). Bu seyretme oranların arttırılabilmesi için tüketim davranışlarını anlamamıza yardım edebilecek uygun ölçüm araçlarının geliştirilmesi ve konuyla ilgili araştırmalar yapılması gereklidir. 
Araştırmalar incelendiğinde, uluslararası nitelikte spor seyircisi güdülerinin neler olduğunu ortaya koyan özellikle çeşitli ölçüm araçlarının bulunduğu görülmektedir (Al-Thibiti, 2004; Funk, Ridinger ve Moorman, 2003; James ve Ross, 2004; Mahony vd., 2002; McDonald, Milne ve Hong, 2002; Pons, Mourali ve Nyeck, 2006; Trail ve James, 2001; Trail, Robinson, Dick ve Gillintine, 2003; Wann, 1995; Zhang, Lam, Bennett ve Connaughton, 2003). Durum Türkiye açısından değerlendirildiğinde konun üzerinde nitelikli çalışma sayısının yeterli olmadığı söylenebilir. Bu çalışmalara örnek olarak ise Gencer, Kiremitçi ve Boyacıŏlu (2011) tarafından yapılan basketbol seyircilerinin seyretme güdüleri ve bağlılık noktaları araştırması; Gencer vd., (2012) tarafindan yapılan futbol takımı seyircilerinin tüketim güdüleri ve bağlılık noktaları arasındaki ilişki, Polat ve Yalçın (2014) tarafından gerçekleştirilen spor seyircileri için içsel ve dışsal güdü ölçeği geliştirme çalışması ve Gencer (2015) tarafından yapılan futbol seyircilerinin seyretme güdüleri ve bağll1ık noktalarının cinsiyetler açısından değerlendirilmesi araştırması gösterilebilir.

Literatürde hâlihazırda bulunan seyirci spor tüketim güdülerine ilişkin ölçüm araçları bir bütün olarak incelendiğinde, çok sayıda seyretme güdüsünün tespit edildiği görülmüştür. Bu araçların genel olarak bulunduğu toplumun spor yönetim yapısını, kültürel özelliklerini ve pazarlama stratejilerini yansıtan biçimde hazırlandığı da söylenebilir. Toplumsal ve kültürel yapı göz önünde bulundurulduğunda ölçüm araçları farklı toplumların spor olgusu yapisına tam anlamıyla uygun bir ölçüm aracı niteliğini taşıyamayacağı görülebilir. Ayrıca ölçüm araçlarının önemli bir kısmının ifade yapıları incelendiğinde güdü mü, tutum mu ya da tatmin mi ölçtükleri konusunda bir karmaşanın oluştuğu da açıktır. Araştırmacılardan Al-Thibiti (2004) de benzer duruma işaret ederek bu konudaki karmaşaya işaret etmiştir. Bununla birlikte bu kadar güdü arasından ne tür güdülerin ise Türkiye'deki spor seyircileri için önemli olduğu da net olarak bilinmemektedir.

Bu sebeple Türkiye'deki spor seyircisi örnekleminden yola çıkarak spor seyircilerinin spor tüketiminde hangi güdülerin etkili olduğu ortaya koymak için Polat ve Yalçın (2014) tarafindan SSIDGÖ ve SSIİGÖ geliştirilmiştir. Bununla birlikte bu çalışma kapsamında bahsi geçen ölçüm araçlarının alt boyut özelliklerini bozmadan daha kısa ve kullanışlı bir yapıya kavuşturulmasının faydalı olacağı düşünülmüştür. Ayrıca ölçeklerin kısa ve kullanışlı özelliklere sahip olması da tutarlı ölçümler açısından önemlidir. $\mathrm{Bu}$ ölçek hem gerçekleştirilecek olan spor organizasyonlarının planlanmasında hem de bu organizasyonlardaki tüketim yoğunluğunun arttrıılmasında gerekli olabilecek yapısal düzenlemelere bilgi sağlamada yardımcı olabilecektir. Dolayısıyla SSIDGÖ ve SSIIIGÖ'nün boyut yapıları korunarak madde sayısının düşürülmesi ve ölçeklerin boyutları arasındaki çoklu etkileşimsel ilişkilerin analiz edilmesi bu çalışmanın hedefleri olarak ele alınmıştır. 


\section{YÖNTEM}

Araştırma evreni ve örneklem: Nicel araştırma yöntemlerinden ilişkisel tarama modeli uygulanarak gerçekleştirilen araştırmanın çalışma evrenini spor müsabakalarını seyreden ve bir üniversitenin farklı bölümlerde okuyan öğrencileri oluşmuştur. Örneklem grubu seçiminde ise amaçsal örnekleme yöntemlerinden ölçüt örnekleme ve uygun (kazara) örnekleme yöntemleri kullanılarak gönüllü katılımcılar seçilmiştir (Büyüköztürk vd., 2017: 95). Gönüllü katılım için oluşturulan katılımcı bilgilendirme formu ve gönüllü katılımcı formu anket başlangıç bölümüne eklenmiştir. İlgili formda araştırmanın amacı, nasıl bir içeriğe sahip olduğu, tahmini yanıtlama süresi, ulaşılması beklenen katılımcı sayısı, araştırmanın potansiyel faydaları, elde edilen kişisel bilgilerin araştırma amaçları dışında kesinlikle gizli tutulacağı gibi bilgiler yer almıştır. Katılımcıların tüm bilgileri okuyarak ve gönüllü katılımcı olmayı kabul ederek imzalamaları istenmiştir.

Veri toplama aracı: Çalışmada veri toplama aracı olarak Polat ve Yalçın (2014) tarafindan geliştirilmiş olan, 7 basamaklı likert tipinde spor seyircileri için dışsal güdü ölçeği (SSIDGÖ) ve Spor Seyircileri İçin İçsel Güdü Ölçeği (SSİ̇GÖ) kullanılmıştır. Polat ve Yalçın (2014) ölçüm araçlarını geliştirirken; yeni bir ölçek geliştirme sürecinde yapılması gerekenlere ilişkin literatür bilgilerine ulaşmış (DeVellis, 1991; Rowan ve Wulff, 2007) ve bunun yanı sıra ölçme değerlendirme uzmanın görüşlerine başvurmuştur. Edinilen bilgiler doğrultusunda çeşitli aşamalarda ölçüm araçları hazırlanmıştır. Bu aşamalar; literatür taraması, nitel görüşme, madde havuzunun oluşturulması, uzman görüşlerinin alınması, yapı geçerliliğinin test edilmesi ve güvenilirlik analizlerinin yapılması aşamalarıdır (Polat ve Yalçın, 2014).

Spor Seyircileri Iç̧in Dışsal Güdü Ölçeği: Toplam 34 madde ve 9 alt boyuttan oluşmuştur. SSIDGÖ için açıklanan toplam varyans 69,77'dir. Alt boyutlar; sosyal paylaşım, popülarite ve güncellik, aile bağları, tanıtım ve medya etkisi, etik değerler, bahis imkanları, oyun bilgisi, kültürel gelişim ve estetik değerler olarak adlandırılmıştır.

Spor Seyircileri İçin İçsel Güdü Ölçeği: Toplam 40 maddeden ve 7 alt boyuttan oluşmuştur. SSIİGÖ için açıklanan toplam varyans 68,48'dir. Alt boyutlar; milli duygular, spor tutkusu, kalite ve rekabet duygusu, taraftarlık, yerel bağlılık, başarı ve beceri düzeyi ile rahatlama ve stresten uzaklaşma olarak tanımlanmıştır.

Verilerin toplanması: Araştırma verilerinin toplanmasında eğitilmiş yardımcılar kullanılmıştır. Örneklem grubuna yüz yüze görüşme yöntemiyle ulaşan bu yardımcılara, anket dağıtılırken dikkat edilmesi gereken hususlar hakkında detaylı bir şekilde bilgi verilmiştir. Dağıtılan ve geri toplanan 350 anketten 310'u geçerli doldurulmuş olarak kabul edilmiş ve değerlendirmeye alınmıştır.

Verilerin analizi: Geliştirilen SSİDGÖ ve SSIİGÖ'nün model yapısını test etmek amacıyla birinci düzey Doğrulayıcı Faktör Analizi (DFA) yapılmıştır. Bu analiz için LISREL paket programı kullanılmıştır (Jöreskog ve Sörbom, 2001). DFA ile uygun görülen gerekli düzenlemeler yapıldıktan sonra ortaya çıkan son yapının alt boyutlarının ve toplam maddelerin alfa iç tutarlılık katsayıları, Spearman-Brown iki yarı test korelasyonları, madde toplam korelasyonları, alt \%27 ve üst \%27'lik grupların farkları ve alt boyutlar arası korelasyon ilişkileri hesaplanmıştır. Son olarak ölçekler arası NCSS istatistik programı kullanılarak Kanonik 
Korelasyon analizi yapılmıştır. Kanonik korelasyon analizi iki değişken seti arasındaki ilişkileri belirlemede kullanılan çok değişkenli istatistiksel analiz tekniğidir. Analizin amacı iki değişken kümesi arasındaki ilişkileri, bahsedilen değişken kümesinin doğrusal fonksiyonları arasındaki maksimum korelasyonları bularak analiz etmektir.

\section{BULGULAR}

\section{Spor Seyircileri İçin Dışsal Güdü Ölçeği (SSİDGÖ) analizleri}

\section{SSIDGÖ birinci DFA analizi}

Tablo 1'de 34 maddeli ve dokuz boyuttan oluşan SSIDGÖ için yapılan DFA bulgularına yer verilmiştir.

Tablo 1. SSIDGGÖ için uyumluluk indeksi değerleri

\begin{tabular}{lccc}
\hline Uyumluluk İndeksi & $\begin{array}{c}\text { Model için elde edilen } \\
\text { değerler }\end{array}$ & İyi uyum & Kabul edilir uyum \\
\hline Ki-Kare $\left(\mathrm{X}^{2}\right)$ & 1075,79 & & \\
Serbestlik Derecesi & 491 & $0 \leq \mathrm{X}^{2} / \mathrm{sd} \leq 2$ & $2 \leq \mathrm{X}^{2} / \mathrm{sd} \leq 5$ \\
Ki-Kare/sd & 2,19 & $0,00 \leq \mathrm{RMSEA} \leq 0,05$ & $0,05 \leq \mathrm{RMSEA} \leq 0,08$ \\
RMSEA & 0,062 & $0,00 \leq \mathrm{SRMR} \leq 0,05$ & $0,05 \leq \mathrm{SRMR} \leq 0,10$ \\
SRMR & 0,064 & $0,95 \leq \mathrm{GFI} \leq 1,00$ & $0,90 \leq \mathrm{GFI} \leq 0,95$ \\
GFI & 0,83 & $0,90 \leq \mathrm{AGFI} \leq 1,00$ & $0,85 \leq \mathrm{AGFI} \leq 0,90$ \\
AGFI & 0,79 & $0,97 \leq \mathrm{CFI} \leq 1,00$ & $0,95 \leq \mathrm{CFI} \leq 0,97$ \\
CFI & 0,94 & $0,97 \leq \mathrm{NNFI} \leq 1,00$ & $0,95 \leq \mathrm{NNFI} \leq 0,97$ \\
NNFI & 0,94 & $0,95 \leq \mathrm{NFI} \leq 1,00$ & $0,90 \leq \mathrm{NFI} \leq 0,95$ \\
NFI & 0,91 & & \\
Critical $N=159,14$ & & & \\
\hline
\end{tabular}

Tablo 1 incelendiğinde, test edilen model için DFA uyum indekslerinden GFI, AGFI, CFI ve NNFI'de ortaya çıkan uyum iyiliği değerlerinin kabul edilebilir sınırların altında olduğu görülmüştür. DFA ile test edilen modelin analizi sonucunda elde edilen uyumluluk indeksi değerlerinin tümünün kabul edilebilir değerleri sağlayamaması sebebiyle modifikasyon önerilerinde en çok tekrar edilen maddeler analizden çıkarılmıştır. Bunun yanı sıra araştırmacılar ölçeğin daha kullanılabilir olmasını düşünerek kavramsal bütünlüğü bozmadan alt boyutlardaki en güçsüz maddelerin analizden çıkarılarak ikinci bir analizin yapılmasına karar verilmiştir.

\section{SSIDGÖ için Ikkinci DFA analizi}

İkinci DFA analizi öncesinde modifikasyon önerilerinde çok tekrar eden maddeler ve faktördeki yük değeri bakımından daha güçsüz görülen maddeler analizden tek tek çıkarılarak modelin uyum indeksindeki değişmeler gözlenmiş ve en iyi sonuç elde edilene kadar kontroller yapılmıştır. Bunun yanı sıra alt boyutlarda geriye kalan maddeler tek tek değerlendirilerek faktör isimleri yeniden gözden geçirilmiştir. Tablo 2'de son analizde elde edilen 25 madde ve 9 boyuttan oluşan SSIDGÖ’nün uyumluluk indeksi değerlerine yer verilmiştir. 
Polat, E. ve Yalçın, H.B. (2020). Spor seyircileri için dışsal ve içsel güdü ölçekleri kısa versiyon uyarlaması ve çok değişkenli ilişkisel bir uyarlama. Spor Bilimleri Araştırmaları Dergisi, 5(1), 111-129.

Tablo 2. Yeniden düzenleme sonrası SSİDGÖ için uyumluluk indeksi değerleri

\begin{tabular}{lccc}
\hline Uyumluluk Indeksi & Model için elde edilen değerler & İyi uyum & Kabul edilir uyum \\
\hline Ki-Kare $\left(\chi^{2}\right)$ & 433,59 & & \\
Serbestlik Derecesi & 239 & & \\
Ki-Kare/sd & 1,81 & $0 \leq \chi^{2} / \mathrm{sd} \leq 2$ & $2 \leq \chi^{2} / \mathrm{sd} \leq 5$ \\
RMSEA & 0,051 & $0,00 \leq \mathrm{RMSEA} \leq 0,05$ & $0,05 \leq \mathrm{RMSEA} \leq 0,08$ \\
SRMR & 0,050 & $0,00 \leq \mathrm{SRMR} \leq 0,05$ & $0,05 \leq \mathrm{SRMR} \leq 0,10$ \\
GFI & 0,90 & $0,95 \leq \mathrm{GFI} \leq 1,00$ & $0,90 \leq \mathrm{GFI} \leq 0,95$ \\
AGFI & 0,86 & $0,90 \leq \mathrm{AGFI} \leq 1,00$ & $0,85 \leq \mathrm{AGFI} \leq 0,90$ \\
CFI & 0,97 & $0,97 \leq \mathrm{CFI} \leq 1,00$ & $0,95 \leq \mathrm{CFI} \leq 0,97$ \\
NNFI & 0,96 & $0,97 \leq \mathrm{NNFI} \leq 1,00$ & $0,95 \leq \mathrm{NNFI} \leq 0,97$ \\
NFI & 0,93 & $0,95 \leq \mathrm{NFI} \leq 1,00$ & $0,90 \leq \mathrm{NFI} \leq 0,95$ \\
Critical $N=201,39$ & & & \\
\hline
\end{tabular}

Tablo 2 incelendiğinde model için elde edilen uyumluluk indeksi değerlerinin tümünün, iyi uyum veya kabul edilebilir uyum sınırları içinde olduğu görülmektedir. Tablo 3'de alt boyutlara göre 25 maddenin standart yükleri, $\mathrm{R}^{2}$ değerleri, $\mathrm{t}$-değerlerine, düzeltilmiş madde toplam korelasyonlarına ve alt-üst \%27'lik gruplar arası fark esti sonuçlarına yer verilmiştir.

Tablo 3. Yeniden düzenleme SSİGÖ standart yükler, $\mathrm{R}^{2}$ ve $t$ değerleri ile düzeltilmiş madde toplam korelasyonu ve alt-üst $\% 27$ 'lik farklar

\begin{tabular}{|c|c|c|c|c|c|}
\hline Boyutlar & $\begin{array}{l}\text { Standart } \\
\text { Yükler }\end{array}$ & $\mathrm{R}^{2}$ & $\stackrel{t}{t}$ & $\begin{array}{c}\text { Düzeltilmi } \\
\text { ş } \\
\text { Madde } \\
\text { toplam } \\
\text { korelasyon }\end{array}$ & $\begin{array}{l}\text { Alt- } \ddot{U} s t \\
\% 27 \text { 'lik } \\
\text { farklar* }\end{array}$ \\
\hline \multicolumn{6}{|l|}{ Sosyal Paylaşım } \\
\hline M17. Etrafımdaki insanlarla konuşmamı sağlamasıdır. & 0,81 & 0,66 & 16,13 & 0,72 & 34,61 \\
\hline M18. Arkadaşlarımla bir araya gelmemi sağlamasıdır. & 0,86 & 0,73 & 17,44 & 0,77 & 30,39 \\
\hline M25. İnsanlarla tanışma firsatı sağlamasıdır. & 0,75 & 0,57 & 14,61 & 0,68 & 44,55 \\
\hline \multicolumn{6}{|l|}{ Popülarite } \\
\hline M11. Sporun, yaşadığım toplum içerisinde yaygın olarak seyredilmesidir. & 0,70 & 0,49 & 12,93 & 0,63 & 46,29 \\
\hline M20. Sporun, yaşadığım toplum içerisinde yaygın olarak yapılmasıdır. & 0,79 & 0,44 & 11,84 & 0,69 & 36,16 \\
\hline M21. Gündemde olmasıdır. & 0,75 & 0,56 & 14,12 & 0,57 & 31,58 \\
\hline \multicolumn{6}{|l|}{ Aile Bağları } \\
\hline M7. Ailemle birlikte hoş vakit geçirmemi sağlamasıdır. & 0,76 & 0,58 & 14,81 & 0,70 & 77,40 \\
\hline M19. Aile üyelerimin bir araya gelmesini sağlamasıdır. & 0,87 & 0,75 & 17,61 & 0,75 & 89,01 \\
\hline M22. Oluşan atmosferi ailemle paylaşmaktan hoşlanmamdır. & 0,81 & 0,66 & 16,20 & 0,73 & 67,75 \\
\hline \multicolumn{6}{|l|}{ Medya Etkisi } \\
\hline M24. Medyadaki spor haberlerinden etkilenmemdir. & 0,69 & 0,57 & 14,61 & 0,58 & 44,66 \\
\hline M27. Medyada geniş yer bulduğu içindir. & 0,81 & 0,66 & 15,32 & 0,62 & 46,01 \\
\hline M33. Müsabaka öncesinde medyanın yarattığı atmosferdir. & 0,63 & 0,40 & 11,19 & 0,55 & 68,81 \\
\hline \multicolumn{6}{|l|}{ Etik Değerler } \\
\hline M12. Diş etkilerden (şike, doping, vb.) uzak olmasıdır. & 0,69 & 0,47 & 12,98 & 0,62 & 53,24 \\
\hline M14. Spor branşlarının şiddetten uzak olmasıdır. & 0,79 & 0,62 & 15,42 & 0,69 & 69,29 \\
\hline $\begin{array}{l}\text { M32. Spor branşlarının olumsuz davranışlardan (kavgalar, küfürler, vb.) } \\
\text { uzak olmasıdır. } \\
\text { Bahis İmkânları }\end{array}$ & 0,91 & 0,83 & 18,68 & 0,77 & 71,96 \\
\hline Madde 2. Bahis oynamamdir. & 0,87 & 0,76 & 18,77 & 0,81 & 19,07 \\
\hline Madde 10. Daha iyi bahis oynayabilmektir. & 0,91 & 0,83 & 19,94 & 0,84 & 15,69 \\
\hline $\begin{array}{l}\text { Madde } 34 \text {. Üzerine bahis oynadığım müsabakaların sonuçlarını merak } \\
\text { etmemdir. } \\
\text { Oyun Bilgisi }\end{array}$ & 0,84 & 0,70 & 17,55 & 0,79 & 28,73 \\
\hline Madde 26. Kurallar hakkında daha fazla bilgi edinmemi sağlamasıdır. & 0,67 & 0,45 & 12,01 & 0,55 & 28,19 \\
\hline Madde 29. Oyun kurallarını bilmemdir. & 0,68 & 0,46 & 12,32 & 0,59 & 42,68 \\
\hline $\begin{array}{l}\text { Madde } 30 \text {. Spor branşlarını tüm yönleriyle anlamamı sağlamasıdır. } \\
\text { Külttürel Gelişim }\end{array}$ & 0,84 & 0,70 & 15,78 & 0,68 & 36,22 \\
\hline Madde 1. Genel kültür seviyemi arttırmasıdır. & 0,68 & 0,47 & 11,06 & 0,55 & 32,31 \\
\hline $\begin{array}{l}\text { Madde 6. Kişisel gelişimimi olumlu yönde etkilemesidir. } \\
\text { Estetik Değerler }\end{array}$ & 0,81 & 0,66 & 12,72 & 0,55 & 22,43 \\
\hline Madde 13. Estetik değeri olan hareketleri barındırmasıdır. & 0,92 & 0,84 & 15,44 & 0,73 & 25,42 \\
\hline $\begin{array}{l}\text { Madde } 15 . \text { Estetik hareketlerin ön planda olduğu mücadelelerden } \\
\text { hoşlanmamdır. }\end{array}$ & 0,79 & 0,63 & 13,53 & 0,73 & 25,24 \\
\hline
\end{tabular}


Polat, E. ve Yalçın, H.B. (2020). Spor seyircileri için dışsal ve içsel güdü ölçekleri kısa versiyon uyarlaması ve çok değişkenli ilişkisel bir uyarlama. Spor Bilimleri Araştırmaları Dergisi, 5(1), 111-129.

Tablo 3 incelendiğinde standart yük değeri, $R^{2}$ değeri ve $t$ değeri acısından en güçlü maddenin Etik değerler alt boyutunda yer alan madde 32 ve bahis imkanları alt boyutundaki madde 10 olduğu, en zayıf maddenin ise kültürel gelişim alt boyutundaki madde 1 ve popülarite alt boyutundaki madde 20'in olduğu görülmektedir. Tüm maddeler için madde-toplam korelasyon değerlerinin 0,55 ve 0,84 arasında değiştiği belirlenmiştir. Alt \%27 ve üst \%27'lik gruplar arası bağımsız örneklem t-testi karşılaşmasında tüm maddelerde $(\mathrm{p}<0,001)$ anlamlı farklılıklar tespit edilmiștir.

Tablo 4. SSIDGÖ Spearman-Brown iki yarı test korelasyonu ve Cronbach’s alfa katsayıları

\begin{tabular}{lccc}
\hline & $\begin{array}{c}\text { Spearman-Brown iki yarı test } \\
\text { korelasyonu }\end{array}$ & $\begin{array}{c}\text { Alt boyut } \\
\text { Cronbach's alfa }\end{array}$ & $\begin{array}{c}\text { Toplam } \\
\text { Cronbach's alfa }\end{array}$ \\
\hline 1. Sosyal Paylaşım & 0,81 & 0,85 & \\
2. Popülarite & 0,73 & 0,79 & \\
3. Aile Bağları & 0,85 & 0,86 & \\
4. Medya Etkisi & 0,71 & 0,76 & \\
5. Etik Değerler & 0,87 & 0,83 & \\
6. Bahis İmkânları & 0,91 & 0,90 & \\
7. Oyun bilgisi & 0,81 & 0,77 & \\
8. Kültürel Gelişim & 0,71 & 0,71 & \\
9. Estetik Değerler & 0,84 & 0,84 & \\
\hline
\end{tabular}

Tablo 4'te toplam ölçeğin ve alt boyutların Cronbach's Alpha iç tutarlılık değerleri incelendiğinde en yüksek değerin Bahis İmkânları $(\alpha=0,90)$ alt boyutunda olduğu, en düşük değerin ise Kültürel Gelişim $(\alpha=0,71)$ alt boyutunda olduğu belirlenmiştir. Toplam ölçeğin iç tutarlılık değerleri ise $\alpha=0,86$ olarak bulunmuştur. Spearman-Brown iki yarı test korelasyonu katsayıları incelendiğinde elde edilen değerlerin 0,71 ile 0,91 arasında olduğu görülmektedir.

\section{Spor Seyircileri İçin İçsel Güdü Ölçeği (SSİiGö) analizleri}

\section{SSİGGÖ için Birinci DFA analizi}

Tablo 5'te 40 madde ve 7 boyuttan oluşan SSİIGÖ’nün DFA uyumluluk indeksi bulgularına ilişkin değerler bulunmaktadır.

Tablo 5. SSİiGÖ için uyumluluk indeksi değerleri

\begin{tabular}{lccc}
\hline Uyumluluk İndeksi & Model için elde edilen değerler & İyi uyum & Kabul edilir uyum \\
\hline Ki-Kare $\left(\chi^{2}\right)$ & 1970,29 & & \\
Serbestlik Derecesi & 719 & & \\
Ki-Kare/sd & 2,74 & $0 \leq \chi^{2} / \mathrm{sd} \leq 2$ & $2 \leq \chi^{2} / \mathrm{sd} \leq 5$ \\
RMSEA & 0,075 & $0,00 \leq \mathrm{RMSEA} \leq 0,05$ & $0,05 \leq \mathrm{RMSEA} \leq 0,08$ \\
SRMR & 0,064 & $0,00 \leq \mathrm{SRMR} \leq 0,05$ & $0,05 \leq \mathrm{SRMR} \leq 0,10$ \\
GFI & 0,76 & $0,95 \leq \mathrm{GFI} \leq 1,00$ & $0,90 \leq \mathrm{GFI} \leq 0,95$ \\
AGFI & 0,72 & $0,90 \leq \mathrm{AGFI} \leq 1,00$ & $0,85 \leq \mathrm{AGFI} \leq 0,90$ \\
CFI & 0,95 & $0,97 \leq \mathrm{CFI} \leq 1,00$ & $0,95 \leq \mathrm{CFI} \leq 0,97$ \\
NNFI & 0,95 & $0,97 \leq \mathrm{NNFI} \leq 1,00$ & $0,95 \leq \mathrm{NNFI} \leq 0,97$ \\
NFI & 0,93 & $0,95 \leq \mathrm{NFI} \leq 1,00$ & $0,90 \leq \mathrm{NFI} \leq 0,95$ \\
Critical $N=129,74$ & & & \\
\hline
\end{tabular}

Tablo 5 incelendiğinde test edilen model için DFA uyum indekslerinden GFI ve AGFI'de elde edilen puanların kabul edilebilir sınırların altında olduğu tespit edilmiştir. DFA ile test edilen 
Polat, E. ve Yalçın, H.B. (2020). Spor seyircileri için dışsal ve içsel güdü ölçekleri kısa versiyon uyarlaması ve çok değişkenli ilişkisel bir uyarlama. Spor Bilimleri Araştırmaları Dergisi, 5(1), 111-129.

modelin analizi sonucunda elde edilen uyumluluk indeksi değerlerinden GFI ve AGFI'nin kabul edilebilir değerleri sağlayamaması sebebiyle modifikasyon önerileri incelenmiş ve en çok tekrar edilen maddeler analizden çıkarılmıştır. Ayrıca ölçeğin daha kullanılabilir olması düşünülerek kavramsal bütünlüğü bozmadan alt boyutlardaki en güçsüz maddelerin analizden çıkarılmasına karar verilmiştir.

\section{SSIIGGÖ ikinci DFA analizi}

$\mathrm{Bu}$ aşamada, son DFA analizi öncesinde modifikasyon önerilerinde en çok tekrar eden maddeler ve faktördeki yük değeri bakımından daha güçsüz görülen maddeler analizden tek tek çıkarılarak modelin uyum indeksindeki değişimler gözlenmiş ve en iyi sonuç elde edilene kadar kontroller yapılmıştır. Bunun yanı sıra alt boyutlarda geriye kalan maddeler tek tek değerlendirilerek faktör isimleri yeniden gözden geçirilmiştir. Tablo 6'da son analizde elde edilen 21 madde ve 7 boyuttan oluşan SSİIGÖ 'nün uyumluluk indeksi değerlerine yer verilmiştir.

Tablo 6. Yeniden düzenleme sonrası SSIİGÖ için uyumluluk indeksi değerleri

\begin{tabular}{lccc}
\hline Uyumluluk İndeksi & Model için elde edilen değerler & İyi uyum & Kabul edilir uyum \\
\hline Ki-Kare $\left(\mathrm{X}^{2}\right)$ & 348,57 & & \\
Serbestlik Derecesi & 168 & & \\
Ki-Kare/sd & 2,07 & $0 \leq \mathrm{X}^{2} / \mathrm{sd} \leq 2$ & $2 \leq \mathrm{X}^{2} / \mathrm{sd} \leq 5$ \\
RMSEA & 0,059 & $0,00 \leq \mathrm{RMSEA} \leq 0,05$ & $0,05 \leq \mathrm{RMSEA} \leq 0,08$ \\
SRMR & 0,048 & $0,00 \leq \mathrm{SRMR} \leq 0,05$ & $0,05 \leq \mathrm{SRMR} \leq 0,10$ \\
GFI & 0,90 & $0,95 \leq \mathrm{GFI} \leq 1,00$ & $0,90 \leq \mathrm{GFI} \leq 0,95$ \\
AGFI & 0,87 & $0,90 \leq \mathrm{AGFI} \leq 1,00$ & $0,85 \leq \mathrm{AGFI} \leq 0,90$ \\
CFI & 0,98 & $0,97 \leq \mathrm{CFI} \leq 1,00$ & $0,95 \leq \mathrm{CFI} \leq 0,97$ \\
NNFI & 0,97 & $0,97 \leq \mathrm{NNFI} \leq 1,00$ & $0,95 \leq \mathrm{NNFI} \leq 0,97$ \\
NFI & 0,95 & $0,95 \leq \mathrm{NFI} \leq 1,00$ & $0,90 \leq \mathrm{NFI} \leq 0,95$ \\
Critical $N=188,45$ & & & \\
\hline
\end{tabular}

Tablo 6 incelendiğinde model için elde edilen uyumluluk indeksi değerlerinin tümünün, iyi uyum veya kabul edilebilir sınırlar içinde olduğu görülmektedir. Tablo 7'de alt boyutlara göre 21 maddenin standart yükleri, $\mathrm{R}^{2}$ değerleri, t-değerlerine, düzeltilmiş madde toplam korelasyonlarına ve alt-üst \%27’lik gruplar arası fark esti sonuçlarına yer verilmişstir.

Tablo 7.Yeniden düzenleme SSIIIGÖ standart yükler, $\mathrm{R}^{2}$ ve $t$ değerleri ile düzeltilmiş madde toplam korelasyonu ve alt-üst $\% 27$ 'lik farklar

\begin{tabular}{|c|c|c|c|c|c|}
\hline Boyutlar & $\begin{array}{l}\text { Standart } \\
\text { Yükler }\end{array}$ & $\mathbf{R}^{2}$ & $t$ Değeri & \begin{tabular}{|c|} 
Düzeltilmiş \\
Madde toplam \\
korelasyon \\
\end{tabular} & $\begin{array}{l}\text { Alt-Üst } \\
\% 27^{\prime} l i k \\
\text { farklar** }\end{array}$ \\
\hline \multicolumn{6}{|l|}{ Milli Duygular } \\
\hline M27. Milli duygularımdır. & 0,83 & 0,69 & 17,12 & 0,77 & 17,15 \\
\hline M29. Milli takımın/sporcunun taraftarı olmamdır. & 0,89 & 0,80 & 19,11 & 0,80 & 20,59 \\
\hline M33. Milli takım1/sporcuyu desteklemek istememdir. & 0,82 & 0,67 & 16,80 & 0,76 & 16,48 \\
\hline \multicolumn{6}{|l|}{ Spor Tutkusu } \\
\hline M8. Sporun hayatımın vazgeçilmez bir parçası olmasıdır. & 0,81 & 0,65 & 16,19 & 0,71 & 33,54 \\
\hline M22. Kendimi sporun tutkunu olarak görmemdir. & 0,82 & 0,68 & 16,69 & 0,71 & 34,25 \\
\hline M30. Sporu sevmemdir. & 0,74 & 0,54 & 14,25 & 0,65 & 18,24 \\
\hline \multicolumn{6}{|l|}{ Rekabet Duygusu } \\
\hline M14. Heyecan duymamı sağlamasıdır. & 0,75 & 0,56 & 14,01 & 0,64 & 15,53 \\
\hline M26. Rekabet düzeyi yüksek mücadelelerden hoşlanmamdır. & 0,76 & 0,58 & 14,38 & 0,64 & 16,36 \\
\hline $\begin{array}{l}\text { M34. Rekorları zorlayan sporcuların (bireysel/takım) verdikleri } \\
\text { mücadeleden hoslanmamdır. }\end{array}$ & 0,71 & 0,50 & 13,02 & 0,59 & 16,20 \\
\hline
\end{tabular}


Polat, E. ve Yalçın, H.B. (2020). Spor seyircileri için dışsal ve içsel güdü ölçekleri kısa versiyon uyarlaması ve çok değişkenli ilişkisel bir uyarlama. Spor Bilimleri Araştırmaları Dergisi, 5(1), 111-129.

Tablo 7 (Devamı). Yeniden düzenleme SSIİGÖ standart yükler, $\mathrm{R}^{2}$ ve $t$ değerleri ile düzeltilmiş madde toplam korelasyonu ve alt-üst \%27'lik farklar

\begin{tabular}{|c|c|c|c|c|c|}
\hline Boyutlar & $\begin{array}{l}\text { Standart } \\
\text { Yükler }\end{array}$ & $\mathbf{R}^{2}$ & $t$ Değeri & \begin{tabular}{|c|} 
Düzeltilmiş \\
Madde toplam \\
korelasyon
\end{tabular} & $\begin{array}{l}\text { Alt-Üst } \\
\% 27 \text { 'lik } \\
\text { farklar* }\end{array}$ \\
\hline \multicolumn{6}{|l|}{ Taraftarlık } \\
\hline M15. Favori takımımın hayatımda önemli bir yere sahip olmasıdır. & 0,81 & 0,65 & 16,42 & 0,76 & 24,16 \\
\hline M23. Kendimi favori takımımın gerçek bir taraftarı olarak görmemdir. & 0,86 & 0,75 & 18,21 & 0,79 & 31,81 \\
\hline M38. Favori takımımı ayrılmaz bir parçam olarak görmemdir. & 0,84 & 0,71 & 17,62 & 0,78 & 36,41 \\
\hline \multicolumn{6}{|l|}{ Yerel Bağlılık } \\
\hline M2. Doğduğum şehrin takımını/sporcusunu desteklemek istememdir. & 0,90 & 0,81 & 19,63 & 0,85 & 68,79 \\
\hline $\begin{array}{l}\text { M9. Kendimi doğduğum şehrin takımının/sporcusunun gerçek bir } \\
\text { taraftarı olarak görmemdir. }\end{array}$ & 0,89 & 0,80 & 19,45 & 0,83 & 94,94 \\
\hline $\begin{array}{l}\text { M17. Yașadığım șehrin takımını/sporcusunu desteklemek } \\
\text { istememdir. }\end{array}$ & 0,83 & 0,69 & 17,44 & 0,79 & 74,65 \\
\hline \multicolumn{6}{|l|}{ Beceri Düzeyi } \\
\hline M6. Oyun zekâsını ön planda tutan sporcuların ilgimi çekmesidir. & 0,63 & 0,39 & 11,50 & 0,66 & 20,76 \\
\hline M10. Farklı taktikleri görmek istememdir. & 0,87 & 0,76 & 17,95 & 0,71 & 31,65 \\
\hline M20. Takımların uyguladıkları taktiklere dikkat etmemdir. & 0,79 & 0,62 & 15,51 & 0,70 & 31,01 \\
\hline \multicolumn{6}{|l|}{ Rahatlama } \\
\hline M1. Stres atmama yardımcı olmasıdır. & 0,76 & 0,58 & 12,93 & 0,61 & 17,66 \\
\hline M3. Can sikıntımı gidermeme yardımcı olmasıdır. & 0,54 & 0,29 & 8,81 & 0,46 & 25,77 \\
\hline M28. Beni rahatlatmasıdır. & 0,67 & 0,45 & 11,31 & 0,44 & 21,11 \\
\hline
\end{tabular}

*p<0,001 sd:166 $\quad \mathrm{n}^{1}-\mathrm{n}^{2}=84$

Tablo 7 incelendiğinde standart yük değeri, $\mathrm{R}^{2}$ değeri ve $t$ değeri acısından en güçlü maddenin yerel bağl1lık alt boyutunda yer alan madde 9 olduğu, en zayıf maddenin ise Rahatlama alt boyutunda yer alan madde 1 olduğu belirlenmiştir. Tablo 7'ye göre tüm maddeler için maddetoplam korelasyon değerlerinin 0,44 ve 0,85 arasında değiştiği görülmektedir. Alt-üst \%27’lik gruplar arası bağımsız örneklem $t$ testi karşılaşmasında tüm maddelerde $(p<0,001)$ anlamlı fark tespit edilmiştir.

Tablo 8. SSİiGÖ Spearman-Brown iki yarı test korelasyonu ve Cronbach's alfa katsayıları

\begin{tabular}{lccc}
\hline & $\begin{array}{c}\text { Spearman-Brown iki yarı test } \\
\text { korelasyonu }\end{array}$ & $\begin{array}{c}\text { Alt boyut } \\
\text { Cronbach's alfa }\end{array}$ & $\begin{array}{c}\text { Toplam } \\
\text { Cronbach's alfa }\end{array}$ \\
\hline 1.Milli Duygular & 0,86 & 0,88 & \\
2.Spor Tutkusu & 0,79 & 0,82 & \\
3. Rekabet Duygusu & 0,74 & 0,78 & \\
4. Taraftarlık & 0,87 & 0,88 & \\
5. Yerel Bağl1lık & 0,88 & 0,91 & \\
6. Beceri Düzeyi & 0,82 & 0,80 & \\
7. Rahatlama & 0,62 & 0,69 & \\
\hline
\end{tabular}

Tablo 8'e göre toplam ölçeğin ve alt boyutların Cronbach Alpha iç tutarlılık değerleri incelendiğinde en yüksek değerin Yerel Bağlılık $(\alpha=0,91)$ alt boyutunda olduğu, en düşük değerin ise Rahatlama $(\alpha=0,69)$ alt boyutunda olduğu belirlenmiştir. Toplam ölçeğin Cronbach Alpha iç tutarlılık değerleri ise $\alpha=0,90$ olarak tespit edilmiştir. Spearman-Brown iki yarı test korelasyonu katsayıları incelendiğinde elde edilen değerlerin 0,62 ile 0,88 arasında olduğu görülmektedir. Ölçüm araçlarının ortalama ve standart sapma değerleri ve iki ölçüm aracına ait toplamda 16 değişkenin birbirleri arasındaki korelasyon katsayıları Tablo 9'da verilmiştir. 
Polat, E. ve Yalçın, H.B. (2020). Spor seyircileri için dışsal ve içsel güdü ölçekleri kısa versiyon uyarlaması ve çok değişkenli ilişkisel bir uyarlama. Spor Bilimleri Araştırmaları Dergisi, 5(1), 111-129.

Tablo 9. SSIDGÖ ve SSIİGÖ alt boyutları ortalama ve standart sapma korelasyon sonuçları (Pearson r)

\begin{tabular}{|c|c|c|c|c|c|c|c|c|c|c|c|c|c|c|c|c|c|c|}
\hline & $\bar{X}$ & $\mathbf{S}$ & $\mathbf{X 1}$ & $\mathbf{X} 2$ & $\mathbf{X 3}$ & $\mathrm{X} 4$ & X5 & X6 & $\mathbf{X 7}$ & X8 & X9 & Y1 & Y2 & Y3 & Y4 & Y5 & Y6 & Y7 \\
\hline \multicolumn{19}{|l|}{ Bağımsız Değişkenler } \\
\hline Sosyal Paylaşım (x1) & 4,90 & 1,58 & 1 & & & & & & & & & & & & & & & \\
\hline Popülarite (x2) & 4,84 & 1,52 & $0,37 * *$ & 1 & & & & & & & & & & & & & & \\
\hline Aile Bağları (x3) & 4,04 & 1,59 & $0,34 * *$ & $0,21 * *$ & 1 & & & & & & & & & & & & & \\
\hline Medya Etkisi (x4) & 4,20 & 1,61 & $0.43 * *$ & $\mathbf{0 , 5 3} * *$ & $0,20 * *$ & 1 & & & & & & & & & & & & \\
\hline Etik Değerler (x5) & 3,65 & 1,77 & $0,31 * *$ & $0,22 * *$ & $0,18^{* *}$ & $0,28 * *$ & 1 & & & & & & & & & & & \\
\hline Bahis İmkânları (x6) & 2,06 & 1,56 & $0,14^{*}$ & $0,18^{* *}$ & $-0,04$ & $0,15^{* *}$ & $-0,09$ & 1 & & & & & & & & & & \\
\hline Oyun Bilgisi (x7) & 5,00 & 2,53 & $0,35 * *$ & $0,34 * *$ & $0,13^{*}$ & $0,38 * *$ & $0,33 * *$ & 0,10 & 1 & & & & & & & & & \\
\hline Kültürel Gelişim (x8) & 5,68 & 1,37 & $0,35 * *$ & $0,16 * *$ & $0,21 * *$ & $0,21 * *$ & $0,34 * *$ & $-0,12^{*}$ & $0,35^{* *}$ & 1 & & & & & & & & \\
\hline Estetik Değerler (x9) & 5,58 & 1,58 & $0,24 * *$ & $0,22 * *$ & 0,07 & $0,22 * *$ & $0,31 * *$ & $0,11^{*}$ & $0,39 * *$ & $0,18 * *$ & 1 & & & & & & & \\
\hline \multicolumn{19}{|l|}{ Bağımlı Değişkenler } \\
\hline Milli Duygular(y1) & 5,99 & 1,37 & $0,18 * *$ & $0,22 * *$ & 0,09 & $0,24 * *$ & $0,17 * *$ & $-0,01$ & $0,26 * *$ & $0,14 * *$ & $0,13^{*}$ & 1 & & & & & & \\
\hline Spor Tutkusu (y2) & 5,69 & 1,43 & $0,24 * *$ & $0,27 * *$ & 0,01 & $0,20 * *$ & $0,31 * *$ & $0,19 * *$ & $0,53 * *$ & $0,23 * *$ & $0,33 * *$ & $0,30 * *$ & 1 & & & & & \\
\hline Rekabet (y3) & 6,27 & 0,96 & $0,17 * *$ & $0,15 * *$ & $0,14^{*}$ & $0,25 * *$ & $0,19 * *$ & 0,06 & $0,39 * *$ & $0,24 * *$ & $0,36 * *$ & $0,41 * *$ & $0,43 * *$ & 1 & & & & \\
\hline Taraftarlık (y4) & 5,44 & 1,64 & $0,17 * *$ & $0,34 * *$ & 0,07 & $0,24 * *$ & 0,06 & $0,27 * *$ & $0,27 * *$ & 0,02 & $0,17 * *$ & $0,47 * *$ & $0,52 * *$ & $0,39 * *$ & 1 & & & \\
\hline Yerel Bağl11ık (y5) & 4,60 & 2,08 & $0,25 * *$ & $0,28 * *$ & $0,15^{* *}$ & $0,31 * *$ & $0,20 * *$ & $0,14 *$ & $0,34 * *$ & 0,03 & $0,16 * *$ & $0,30 * *$ & $0,32 * *$ & $0,20 * *$ & $0,47 * *$ & 1 & & \\
\hline Beceri Düzeyi (y6) & 5,53 & 1,46 & $0,25 * *$ & $0,23 * *$ & $0,11^{*}$ & $0,23 * *$ & $0,38 * *$ & $0,11^{*}$ & $0,59 * *$ & $0,30 * *$ & $0,48 * *$ & $0,23 * *$ & $0,63 * *$ & $0,52 * *$ & $0,34 * *$ & $0,28 * *$ & 1 & \\
\hline Rahatlama (y7) & 5,76 & 1,25 & $0,29 * *$ & $0,26 * *$ & $0,23 * *$ & $0,23 * *$ & $0,12 * *$ & $0,20 * *$ & $0,29 * *$ & $0,27 * *$ & $0,24 * *$ & $0,17 * *$ & $0,37 * *$ & $0,44 * *$ & $0,27 * *$ & $0,17 *$ & $0,38 * *$ & 1 \\
\hline
\end{tabular}

$* \mathrm{p}<0,05 \quad * * \mathrm{p}<0,01$ 
Tablo 9 incelendiğinde SSIDGÖ açısından en yüksek aritmetik ortalama değerinin estetik değerler boyutunda olduğu tespit edilmiştir. SSİİÖ için ise en yüksek aritmetik ortalama değerinin rekabet duygusu alt boyutunda olduğu görülmektedir. Tablo incelendiğinde bağımlı ve bağımsız değişkenlere ait alt boyutların çoğunda anlamlı ilişkilerin olduğu gözlenmiştir. SSIDGÖ alt boyutları arasında en yüksek korelasyon değerinin x2 (popülarite) ile x4 (medya etkisi) değişkenleri arasında $(\mathrm{r}=0,53, \mathrm{p}<0,01)$ orta düzey anlamlı pozitif ilişkinin olduğu belirlenmiştir. SSİIGÖ alt boyutları arasında en yüksek korelasyon değerinin y2 (spor tutkusu) ile y6 (beceri düzeyi) değişkenleri arasında $(r=0,63, p<0,01)$ orta düzey pozitif anlamlı ilişkinin olduğu görülmüştür. SSIDGÖ ve SSİIGÖ alt boyutlarına dair setler arası karşılaştırmada ise genel olarak anlamlı pozitif ilişkilerin bulunduğu ve en güçlü korelasyon değerinin de $\mathrm{x} 7$ (oyun bilgisi) ve y6 (beceri düzeyi) değişkenleri arasında $(r=0,59, p<0,01)$ orta düzey anlamlı pozitif ilişkinin olduğu tespit edilmiştir.

\section{İki Ölçek İçinKanonik Korelasyon Analizi (KKA)}

Kanonik korelasyon analizi, rastgele iki değişken seti arasındaki ilişkinin tanımlanmasını ve hesaplanmasını araştıran çok değişkenli istatistiğin başlıca yöntemlerinden biridir (Eubank ve Hsing, 2008). KKA, nın temel amacı iki değişken setinin her biri için maksimum korelasyonlu ve birim varyanslı doğrusal bileşenler oluşturarak değişken setleri arasındaki ilişkiyi ortaya koyan en uygun boyutluluğu belirlemektir (Harris, 2001). KKA, çoklu bağımsız değişkenler ile çoklu bağımlı değişkenler arasındaki karşılıklı ilişkiyi inceleyen istatistiki bir model olarak kullanılır. Böylece değişken setleri arasında doğrusal bir ilişkili olup olmadığı analiz edilebilir (Pugh ve Hu, 1991). Kanonik korelasyon analizi için öncelikle bağımlı ve bağımsız değişken setleri oluşturulmuştur. SSIDGÖ içerisinde yer alan 9 alt boyut bağımsız değişkenleri oluştururken SSIIIGÖ içerisinde yer alan 7 alt boyut ise bağımlı değişkenleri oluşturmuştur.

Tablo 10'da SSIDGÖ ve SSIİGÖ’ye ait alt boyutlar arasında oluşan kanonik değişken çiftlerinin karşılaştırmalı analizlerine yer verilmiştir. Kanonik fonksiyon, bağımlı kanonik değişkenler ile bağımsız kanonik değişkenler arasındaki ilişkinin ifadesidir. Kanonik fonksiyonun gücü, kanonik korelasyon katsayısı ile ölçülür. Analizde, en az sayıda değişkene sahip olan alt boyuttaki değişken sayısı kadar kanonik fonksiyon elde edilir ve kanonik korelasyon hesaplanır. Bu çalışmada 9 bağımsız ve 7 bağımlı değişken olması sebebiyle hesaplanabilecek kanonik fonksiyon sayıs1 ve kanonik korelasyon katsayıs1 7'dir. Kanonik değişken çiftleri arasındaki korelasyon (kanononik korelasyon değeri) iki veri seti arasındaki ilişkinin yapısını gösterir.

Tablo 10. Kanonik değişkenlere ait analiz sonuçları

\begin{tabular}{cccccccc}
\hline $\begin{array}{c}\text { Kanonik } \\
\text { Değişkenler }\end{array}$ & $\begin{array}{c}\text { Kanonik } \\
\text { Korelasyon }\end{array}$ & $\begin{array}{c}\text { R-Kare } \\
\text { Değeri }\end{array}$ & F değeri & $\begin{array}{c}\text { Serbestlik } \\
\text { Derecesi } \\
\text { Sayısı }\end{array}$ & $\begin{array}{c}\text { Serbestlik } \\
\text { Derecesi } \\
\text { Yoğunluğu }\end{array}$ & $\begin{array}{c}\text { Anlamlılık } \\
\text { Seviyesi }\end{array}$ & $\begin{array}{c}\text { Lambda } \\
\text { Değeri }\end{array}$ \\
\hline $\mathrm{U}_{1-} \mathrm{V}_{1}$ & 0,72 & 0,52 & 6,39 & 63 & 1662 & 0,00 & 0,29 \\
$\mathrm{U}_{2-} \mathrm{V}_{2}$ & 0,44 & 0,19 & 3,18 & 48 & 1456 & 0,00 & 0,61 \\
$\mathrm{U}_{3-} \mathrm{V}_{3}$ & 0,33 & 0,11 & 2,39 & 35 & 1248 & 0,00 & 0,76 \\
$\mathrm{U}_{4-} \mathrm{V}_{4}$ & 0,28 & 0,08 & 1,96 & 24 & 1037 & 0,00 & 0,86 \\
$\mathrm{U}_{5-} \mathrm{V}_{5}$ & 0,22 & 0,05 & 1,41 & 15 & 823 & 0,13 & 0,93 \\
$\mathrm{U}_{6-} \mathrm{V}_{6}$ & 0,11 & 0,01 & 0,73 & 8 & 598 & 0,67 & 0,98 \\
$\mathrm{U}_{7-} \mathrm{V}_{7}$ & 0,08 & 0,01 & 0,65 & 3 & 300 & 0,58 & 0,99 \\
\hline
\end{tabular}


Polat, E. ve Yalçın, H.B. (2020). Spor seyircileri için dışsal ve içsel güdü ölçekleri kısa versiyon uyarlaması ve çok değişkenli ilişkisel bir uyarlama. Spor Bilimleri Araşstırmaları Dergisi, 5(1), 111-129.

Tablo 10 incelendiğinde birinci kanonik değişken çifti yani $\mathrm{U}_{1}$ ve $\mathrm{V}_{1}$ arasında hesaplanan kanonik korelasyonun 0,$72 ; \mathrm{U}_{2}$ ve $\mathrm{V}_{2}$ değişken çifti arasında 0,$44 ; \mathrm{U}_{3}$ ve $\mathrm{V}_{3}$ değişsken çifti arasında 0,33 ve $\mathrm{U}_{4}$ ve $\mathrm{V}_{4}$ değişken çifti arasında 0,28 olduğu, istatistiksel açıdan dört değişken çiftinin de anlamlı bulunduğu $(\mathrm{p}<0,05)$ görülmektedir. Diğer değişken çiftlerinin ise önemsiz olduğu belirlenmiştir. KKA da anlamlı olan kanonik korelasyon katsayıları yorumlanabilmektedir. Bu yüzden dört değişken çifti üzerinden analizler devam ettirilecektir. $\mathrm{U}_{1}$ ve $\mathrm{V}_{1}$ ' $\mathrm{i}$ ifade eden birinci değişken çifti ele alındığında dışsal seyretme güdülerinden oluşan bağımsız değişkenler içsel seyretme güdülerinden oluşan bağımlı değişkenleri \%52 oranında açıklamaktadır. İkinci değişken çifti \%19, üçüncü değişken çifti \%11 ve dördüncü değişken çifti \%8 oranında bağımlı değişkeni açıklamaktadır. Anlamlı olan dört kanonik değişken çifti için hesaplanan standartlaştırılmış kanonik katsayılar tablo 11 de verilmiştir.

Tablo 11. Dört kanonik değişken çifti için standartlaştırılmış kanonik katsayılar

\begin{tabular}{|c|c|c|c|c|}
\hline & $\begin{array}{c}\text { 1.Fonksiyon** } \\
\text { Standardize edilmiş } \\
\text { Kanonik katsayilar }\end{array}$ & $\begin{array}{l}\text { 2. Fonksiyon** } \\
\text { Standardize edilmiş } \\
\text { Kanonik katsay1lar }\end{array}$ & $\begin{array}{l}\text { 3.Fonksiyon** } \\
\text { Standardize edilmiş } \\
\text { Kanonik katsayılar }\end{array}$ & $\begin{array}{l}\text { 4. Fonksiyon** } \\
\text { Standardize edilmis } \\
\text { Kanonik katsayılar }\end{array}$ \\
\hline \multicolumn{5}{|l|}{$X$ değişken seti } \\
\hline Sosyal Paylaşım (x1) & 0,00 & 0,20 & $-0,09$ & 0,26 \\
\hline Popülarite (x2) & $-0,02$ & 0,60 & $-0,35$ & $-0,16$ \\
\hline Aile Bağları (x3) & $-0,02$ & 0,22 & $\mathbf{0 , 6 0}$ & 0,11 \\
\hline Medya Etkisi (x4) & 0,01 & 0,09 & 0,51 & 0,64 \\
\hline Etik Değerler (x5) & $-0,24$ & $-0,32$ & $-0,47$ & 0,32 \\
\hline Bahis İmkânları (x6) & $-0,11$ & 0,49 & $-0,21$ & $-0,50$ \\
\hline Oyun Bilgisi (x7) & $-0,66$ & $-0,16$ & $-0,40$ & 0,16 \\
\hline Kültürel Gelişim (x8) & $-0,09$ & $-0,08$ & 0,46 & $-0,56$ \\
\hline Estetik Değerler (x9) & $-0,30$ & $-0,20$ & 0,47 & $-0,49$ \\
\hline \multicolumn{5}{|l|}{ Y Değişken seti } \\
\hline Milli Duygular(y1) & $-0,11$ & $-0,09$ & 0,08 & 0,56 \\
\hline Spor Tutkusu (y2) & $-0,31$ & $-0,17$ & $-0,85$ & $-0,11$ \\
\hline Rekabet Duygusu (y3) & $-0,11$ & $-0,34$ & 0,65 & 0,01 \\
\hline Taraftarlık (y4) & 0,20 & $\mathbf{0 , 8 1}$ & $-0,24$ & $-0,58$ \\
\hline Yerel Bağl1lık (y5) & $-0,22$ & 0,22 & 0,00 & $\mathbf{0 , 9 0}$ \\
\hline Beceri Düzeyi (y6) & $-0,63$ & $-0,37$ & 0,08 & $-0,23$ \\
\hline Rahatlama (y7) & $-0,07$ & 0,64 & 0,53 & $-0,23$ \\
\hline
\end{tabular}

Tablo 11'e göre birinci kanonik değişken çifti yani $\mathrm{U}_{1}$ ve $\mathrm{V}_{1}$ arasında orijinal değişkenlerin kanonik değişkene ne ölçüde katkı yaptığı görülmektedir. Buna göre $\mathrm{X}$ değişken setindeki dişsal seyretme güdülerinden birinci kanonik değişkeni en çok açıklayan orijinal değişkenler sirasıyla; oyun bilgisi (x7), estetik değerler (x9), etik değerler (x5) ve bahis imkanları (x6) değişkenleridir. Y değişken setindeki içsel seyretme güdülerinden birinci kanonik değişkeni en çok açıklayan değişkenler ise sırasıyla; beceri düzeyi (y6), Spor tutkusu (y2), yerel bağlılık (y5), taraftarlık (y4), rekabet duygusu (y3) ve milli duygular (y1) boyutlarıdır.

$\mathrm{U}_{2}$ ve $\mathrm{V}_{2}$ değişken çifti için $\mathrm{X}$ değişken setindeki dişsal seyretme güdülerinden ikinci kanonik değişkeni en çok açıklayan orijinal değişkenler sırasıyla; popülarite (x2), bahis imkanlar1 (x6) ve etik değerler (x5) boyutlarıdır. Y değişken setindeki içsel seyretme güdülerinden ikinci kanonik değişkeni en çok açıklayan değişkenler ise sırasıyla; taraftarlık (y4), rahatlama (y7) ve beceri düzeyi (y6) değişkenleridir. 
Polat, E. ve Yalçın, H.B. (2020). Spor seyircileri için dışsal ve içsel güdü ölçekleri kısa versiyon uyarlaması ve çok değişkenli ilişkisel bir uyarlama. Spor Bilimleri Araştırmaları Dergisi, 5(1), 111-129.

$\mathrm{U}_{3}$ ve $\mathrm{V}_{3}$ değişken çifti için $\mathrm{X}$ değişken setindeki dişsal seyretme güdülerinden ikinci kanonik değişkeni en çok açıklayan orijinal değişkenler sırasıyla; aile bağları (x3), medya etkisi (x4), etik değerler (x5) ve estetik değerler (x9) boyutlarıdır. Y değişken setindeki içsel seyretme güdülerinden ikinci kanonik değişkeni en çok açıklayan değişkenler ise sırasıyla; spor tutkusu (y2), rekabet duygusu (y3) ve rahatlama (y7) boyutlarıdır.

$\mathrm{U}_{4}$ ve $\mathrm{V}_{4}$ değişken çifti için $\mathrm{X}$ değişken setindeki dişsal seyretme güdülerinden ikinci kanonik değişkeni en çok açıklayan orijinal değişkenler sırasıyla; medya etkisi (x4), kültürel gelişim (x8) ve bahis imkanları boyutlarıdır. Y değişken setindeki içsel seyretme güdülerinden ikinci kanonik değişkeni en çok açıklayan değişkenler ise sırasıyla; yerel bağlılık (y5), taraftarlık (y4) ve milli duygular (y1) değişkenleridir.

Orijinal değişkenin, kendi kanonik değişkeniyle arasındaki basit doğrusal korelasyona ise "kanonik yük" adı verilmektedir. İlgili değişkenin kendi kanonik değişkenine dolayısıyla kanonik korelasyon katsayısına yaptığı katkının ne kadar güçlü olduğunun belirlenmesini sağlamaktadır. Kanonik çapraz yük ise orjinal bağımlı değişkenler ile bağımsız kanonik değişkenler arasındaki basit doğrusal korelasyon veya orijinal bağımsız değişkenler ile bağımlı kanonik değişkenler arasındaki basit doğrusal korelasyonu belirtmektedir. Böylece yüksek korelasyona sahip değişkenin, çapraz setteki kanonik değişkene yaptığı katkının gücü ölçülebilmektedir (Hair, Anderson, Tatham ve Black, 1998). Tablo 12'de anlamlı olan dört kanonik değişken çiftine ait bağımlı ve bağımsız kanonik değişkenler için kanonik yükler ve çapraz yükler gösterilmektedir.

Tablo 12. Bağımlı ve bağımsız değişkenler için kanonik yükler ve çapraz yükler

\begin{tabular}{|c|c|c|c|c|c|c|c|c|}
\hline & \multicolumn{2}{|c|}{ 1. Fonksiyon $* *$} & \multicolumn{2}{|c|}{ 2. Fonksiyon** } & \multicolumn{2}{|c|}{ 3. Fonksiyon** } & \multicolumn{2}{|c|}{ 4. Fonksiyon** } \\
\hline & $\begin{array}{l}\text { Kanonik } \\
\text { Yükler }\end{array}$ & $\begin{array}{l}\text { Çapraz } \\
\text { Yükler }\end{array}$ & $\begin{array}{c}\text { Kanonik } \\
\text { Yükler }\end{array}$ & $\begin{array}{l}\text { Çapraz } \\
\text { Yükler }\end{array}$ & $\begin{array}{l}\text { Kanonik } \\
\text { Yükler }\end{array}$ & $\begin{array}{l}\text { Çapraz } \\
\text { Yükler }\end{array}$ & $\begin{array}{l}\text { Kanonik } \\
\text { Yükler }\end{array}$ & $\begin{array}{l}\text { Çapraz } \\
\text { Yükler }\end{array}$ \\
\hline \multicolumn{9}{|l|}{$X$ değişken seti } \\
\hline Sosyal Paylaşım (x1) & $-0,43$ & $-0,31$ & 0,38 & 0,17 & 0,16 & 0,05 & 0,28 & 0,08 \\
\hline Popülarite (x2) & $-0,39$ & $-0,28$ & 0,68 & $\mathbf{0 , 3 0}$ & $-0,09$ & $-0,03$ & 0,14 & 0,04 \\
\hline Aile Bağları (x3) & $-0,19$ & $-0,14$ & 0,30 & 0,13 & 0,60 & 0,20 & 0,24 & 0,07 \\
\hline Medya Etkisi (x4) & $-0,42$ & $-0,30$ & 0,41 & 0,18 & 0,29 & 0,10 & 0,54 & 0,15 \\
\hline Etik Değerler (x5) & $-0,57$ & $-0,41$ & $-0,24$ & $-0,11$ & $-0,14$ & $-0,04$ & 0,32 & 0,09 \\
\hline Bahis İmkânları (x6) & $-0,18$ & $-0,13$ & 0,63 & 0,28 & $-0,23$ & $-0,08$ & $-0,40$ & $-0,11$ \\
\hline Oyun Bilgisi (x7) & $-0,90$ & $-0,65$ & 0,02 & 0,01 & $-0,11$ & $-0,04$ & 0,12 & 0,03 \\
\hline Kültürel Gelişisim (x8) & $-0,45$ & $-0,32$ & $-0,10$ & $-0,04$ & 0,40 & 0,14 & $-0,20$ & $-0,06$ \\
\hline Estetik Değerler (x9) & $-0,66$ & $-0,48$ & $-0,10$ & $-0,04$ & 0,29 & 0,10 & $-0,31$ & $-0,09$ \\
\hline \multicolumn{9}{|l|}{ Y Değişken seti } \\
\hline Milli Duygular(y1) & $-0,38$ & $-0,27$ & 0,19 & 0,08 & 0,09 & 0,03 & 0,43 & 0,12 \\
\hline Spor Tutkusu (y2) & $-0,78$ & $-0,57$ & 0,14 & 0,06 & $-0,42$ & $-0,14$ & $-0,18$ & $-0,05$ \\
\hline Rekabet Duygusu (y3) & $-0,61$ & $-0,44$ & $-0,01$ & 0,00 & 0,50 & 0,17 & $-0,08$ & $-0,02$ \\
\hline Taraftarlık (y4) & $-0,39$ & $-0,28$ & 0,69 & $\mathbf{0 , 3 1}$ & $-0,21$ & $-0,07$ & $-0,08$ & $-0,02$ \\
\hline Yerel Bağl1lık (y5) & $-0,47$ & $-0,34$ & 0,46 & 0,21 & $-0,11$ & $-0,04$ & 0,65 & 0,19 \\
\hline Beceri Düzeyi (y6) & $-0,93$ & $-0,67$ & $-0,10$ & $-0,05$ & 0,02 & 0,01 & $-0,19$ & $-0,05$ \\
\hline Rahatlama (y7) & $-0,48$ & $-0,34$ & 0,53 & 0,23 & 0,49 & 0,16 & $-0,26$ & $-0,07$ \\
\hline
\end{tabular}

Tablo 12 incelendiğinde 1. Fonksiyon $\left(\mathrm{U}_{1}\right.$ ve $\left.\mathrm{V}_{1}\right)$ için bağımsız oyun bilgisi (x7) değişkeninin bağımlı ve bağımsız kanonik değişkenle en yüksek basit doğrusal korelasyona sahip olduğu 
Polat, E. ve Yalçın, H.B. (2020). Spor seyircileri için dışsal ve içsel güdü ölçekleri kısa versiyon uyarlaması ve çok değişkenli ilişkisel bir uyarlama. Spor Bilimleri Araşstırmaları Dergisi, 5(1), 111-129.

görülmektedir. Yani bağımlı ve bağımsız kanonik değişkenlere en yüksek katkıyı bu değişken yapmaktadır. Yine 1. Fonksiyon için bağımlı beceri düzeyi (y6) değişkeninin bağımlı ve bağımsız kanonik değişkenle en yüksek basit doğrusal korelasyon katsayısına sahip olduğu belirlenmiştir.

2. Fonksiyon $\left(U_{2}\right.$ ve $\left.V_{2}\right)$ için bağımlı ve bağımsız kanonik değişkenlere en yüksek katkıyı bağımsız popülarite (x2) ve bağımlı taraftarlık (y4) değişkenleri yapmaktadır. 3. Fonksiyon $\left(\mathrm{U}_{3}\right.$ ve $\mathrm{V}_{3}$ ) için bağımlı ve bağımsız kanonik değişkenlere en yükssek katkıyı; bağımsız aile bağları (x3) değişkeni ve bağımlı rekabet duygusu (y3) değişkeni yapmıştır. 4. Fonksiyon ( $\mathrm{U}_{4}$ ve $\mathrm{V}_{4}$ ) için ise bağımlı ve bağımsız kanonik değişkenlere en yüksek katkıyı bağımsız medya etkisi (x4) değişkeni ve bağımlı yerel bağlılık (y5) değişkeni yapmıştır.

\section{TARTIŞMA ve SONUÇ}

$\mathrm{Bu}$ araştırmada Polat ve Yalçın (2014) tarafından geliştirilen SSİDGÖ ve SSİIGÖ için DFA kullanılarak geçerli güvenilir ve özellikle daha kısa ve kullanışlı ölçüm araçlarının elde edilmesi amaçlanmıştır. İki ölçek için de ilk yapılan DFA analizlerinde özellikle GFI ve AGFI değerlerinin beklenen uyumu göstermediği görülmüştür. Sonraki yapılan DFA sonuçlarına göre, SSIDGÖ için 9 alt boyutlu yapı korunmuş, 34 olan madde sayısı ise 25 'e düşürülmüş̧ür. SSIİGÖ için ise yine 7 alt boyut değişmezken 40 maddeli ölçek 21'e düşürülmüştür. Bu iki ölçeğin de DFA uyum indekslerine göre (SSIDGÖ sonuçları: Ki kare/sd=1,81 RMSEA=0,051 $\mathrm{SRMR}=0,050 \mathrm{GFI}=0,90 \mathrm{AGFI}=0,86 \mathrm{CFI}=0,97 \mathrm{NFI}=0,93 \mathrm{NNFI}=0,96$; SSİंGÖ sonuçları: Ki kare/sd= 2,07 RMSEA=0,059 SRMR=0,048 GFI=0,90 AGFI=0,87 CFI=0,98 NFI=0,95 $\mathrm{NNFI}=0,97$ ) iyi uyum veya kabul edilebilir uyum sınırları içinde olduğu tespit edilmiştir.

DFA bağlantılı literatür incelendiğinde, elde edilen modelin uyumunda Ki-kare değerinin " 0 "a ne kadar yakın olursa o denli iyi olacağı belirtilmektedir. Bununla beraber "p" (anlamlılık) değerinin de manidar çıkması modelin uygunluğu için gerekli görülürken, bu değerin örneklem sayısı arttıkça etkilendiği de ayrıca belirtilmektedir (Çokluk, Şekercioğlu ve Büyüköztürk, 2010; Schumacker ve Lomax, 2004; Yılmaz ve Çelik, 2009). Örneklem sayısının etkilerini ortadan kaldırmak için Ki-karenin serbestlik derecesine oranı temel alınması önerilmektedir. $\mathrm{X}^{2}$ /sd oranı için 3 ve daha düşük değerler iyi, 5'e kadar olan değerler ise yeterli olarak kabul edilmektedir (Kline, 1994; Sümer, 2000). İki ölçüm aracı için yapılan analizler sonucunda elde edilen değerler $\left(\mathrm{x}^{2} / \mathrm{sd}=1,81\right.$ ve 2.07$)$ oldukça makul sınırlar içinde yer almıştır.

DFA'da diğer uyum iyiliği ölçütleri bağlamında RMSEA ve SRMR için; 0,05'in altında kalan değerlerin iyi uyum, 0,05 ile 0,10 arasının kabul edilir uyum, NFI ve GFI için; 0,90 ve 0,95 arası değerlerin kabul edilebilir uyum, 0,95 ve 1 arasının iyi uyum, NNFI ve CFI için; 0,95 ve 0,97 arası değerlerin kabul edilebilir uyum 0,97 ve 1 arası değerlerin de iyi uyum, AGFI için ise; 0,85 ve 0,90 arası değerlerin kabul edilir uyum, 0,90 ve 1 arası değerlerin de iyi uyum göstergesi olduğu belirtilmektedir (Schermelleh, Moosbrugger ve Müller, 2003; Y1lmaz ve Çelik, 2009). İki ölçüm aracına ilişkin sonuçlara göre tüm uyum iyiliği ölçütlerinin uygun sınırlar içinde kaldığ 1 görülmüştür (SSIDGÖ sonuçları: RMSEA= 0,051 SRMR= 0,050 GFI= 
Polat, E. ve Yalçın, H.B. (2020). Spor seyircileri için dışsal ve içsel güdü ölçekleri kısa versiyon uyarlaması ve çok değişkenli ilişkisel bir uyarlama. Spor Bilimleri Araşstırmaları Dergisi, 5(1), 111-129.

0,90 AGFI= 0,86 CFI=0,97 NFI=0,93 NNFI= 0,96; SSïIGÖ sonuçlarl: $\mathrm{Ki}$ kare/sd= 2,07 RMSEA $=0,059$ SRMR $=0,048 \mathrm{GFI}=0,90 \mathrm{AGFI}=0,87 \mathrm{CFI}=0,98 \mathrm{NFI}=0,95 \mathrm{NNFI}=0,97$ ).

Uyum iyiliği ölçütlerinin incelenmesi sonrasında 25 maddelik ve 20 maddelik iki ayrı ölçüm aracına ilişkin standart yük değerlerine, $t$-değerlerine ve $\mathrm{R}^{2}$ değerine bakılmıştır. Gözlenen değişkenin bağlı olduğu gizli değişkenle olan ilişkisinde ortaya çıkan t-değerinin 1,96'l1k değeri aştığ 1 taktirde 0,05 düzeyinde anlamlı olacağına, 2,56' lık değeri aştığı taktirde ise 0,01 düzeyinde anlamlı olacağı alan yazın tarafından ifade edilmektedir (Çokluk vd., 2010). Bu araştırmada, SSIDGÖ için en küçük t-değerinin 11,06; SSIİGÖ için ise en küçük t-değerinin 8,81 bulunduğu ve bu sonuçların 2,56'lık değerin üzerinde olduğu gözlenmiştir.

Doğrulayıcı faktör analizi sonucu ortaya çıkan standart yük değerleri, her bir gözlenen değişken ile bağlı olduğu gizili değişkenin arasındaki korelasyona işaret etmektedir. $\mathrm{R}^{2}$ ise gözlenen değişken ile gizli değişken arasındaki ilişkinin gücünü göstermektedir. SSİDGÖ için standart yük değerlerinin $0,92-0,63 ; \mathrm{R}^{2}$ değerinin $0,84-0,40$ arasında olduğu; SSİİÖ için ise standart yük değerlerinin $0,90-0,54 ; \mathrm{R}^{2}$ değerinin $0,81-0,29$ arasında olduğu belirlenmiştir. Bulgulardan hareketle elde edilen maddelerin standart yüklerinin ve $\mathrm{R}^{2}$ değerlerinin ortaya çıkan yapı için oldukça makul sınırlar içinde olduğu söylenebilir.

Ölçüm araçlarının güvenilirlik analizleri çerçevesinde her iki ölçek için de alfa katsayısı oranları $\alpha=0,91$ ve 0,69 arasında olduğu Spearman-Brown iki yarı test korelasyon sonuçlarının da $\mathrm{SB}=0,91$ ve 0,62 arasında olduğu görülmüştür. Alpar (2010) 0,60 ve üzerindeki alfa güvenilirlik katsayısının yeterli olacağı ifade edilmektedir. Bu bilgiler 1şı̆̆ında elde edilen sonuçların makul seviyede olduğu belirtilebilir. Her iki ölçek için tüm maddelerin maddetoplam korelasyon değerlerinin pozitif yönde ve 0,44 ve 0,85 arasında değiștiği görülmektedir. Madde-toplam korelasyonların pozitif ve 0,30 ve daha üstü değerlerde olması maddelerin benzer davranışları örneklediğini ve testin iç tutarlılığının yüksek olduğunu göstermektedir (Büyüköztürk, 2006). Madde toplam korelasyon sonuçlarının tüm maddeler için iyi değerlere sahip olduğu söylenebilir. Alt \%27 ile üst \%27’lik gruplar arası karşılaştırmada tüm maddeler anlamlı farklılık göstermiştir. Elde edilen sonuca göre her iki ölçek için tüm maddelerin iyi bir ayırt ediciliğe sahip olduğu görülmüştür.

Doğrulayıcı Faktör analizi sonucunda oluşan yapının alt boyutlarının korelasyon katsayıları incelendiğinde, SSİDGÖ için alt boyutlar arası ilişkiler incelendiğinde -0,12 ile 0,54 arasında ve genel itibarıyla anlamlı korelasyonlar bulunmuştur. SSİ́GÖ için ise alt boyutlar arası ilişkiler incelendiğinde 0,17 ile 0,64 arasında pozitif yönde ve bütünüyle anlamlı korelasyonlar bulunmuştur.

Özet olarak seyircileri sporu seyretmeye iten güdüleri ortaya koymak için geliştirilen SSIDGÖ ve SSIİGÖ kısa versiyonlarının yapılacak araştırmalarda daha kullanışlı bir biçimde, geçerli ve güvenilir ölçekler olarak kullanılabileceği söylenebilir. Bununla birlikte araştırmacılar ölçüm aracının geliştirilme süreçlerine yeni örneklemler üzerinde de çalışarak davam edilmesi gerektiği düşüncesinde de hemfikirdirler.

Ölçeklerin ortalamaları dikkate alındığında SSİDGÖ açısından en yüksek aritmetik ortalama değerinin estetik değerler, SSİ̈GÖ için ise en yüksek aritmetik ortalama değerinin rekabet duygusu alt boyutlarında olduğu görülmektedir. Gencer vd. (2012) tarafinda yapılan 
Polat, E. ve Yalçın, H.B. (2020). Spor seyircileri için dışsal ve içsel güdü ölçekleri kısa versiyon uyarlaması ve çok değişkenli ilişkisel bir uyarlama. Spor Bilimleri Araşstırmaları Dergisi, 5(1), 111-129.

araştırmada ise genel olarak sosyal etkileşim ve takım bağlılığı boyutlarının ön plana çıktığı ifade edilmiştir. Bununla birlikte araştırmanın alt gruplarında ise farklı boyutların öne çıktığı da ileri sürülmüş ve bu sonuç başka özelliklere sahip kitlelerde da farklı seyretme güdülerinin öne çıkabileceğini düşündürtmüştür.

Araştırmada ölçek alt boyutlarının etkileşimsel ilişkisi Kanonik korelasyon analizi ile incelenmiştir. Kanonik korelasyon sonuçları incelendiğinde ilk dört değişken çiftinin anlamlı olduğu bulunmuştur. Yine Gencer vd. (2012) seyretme güdüleri ve bağlllık noktaları üzerine gerçekleştirdikleri araştırma kapsamında iki farklı taraftar grubuna yaptıkları Kanonik korelasyon analizi sonucu bir grupta beş diğer grupta ise iki değişken çiftinin anlamlı olduğunu bulmuşladır. Bu araştırma kapsamında daha çok ön plana çıkan ilk iki değişken çifti ele alındığında dışsal seyretme güdülerinden oluşan bağımsız değişkenler içsel seyretme güdülerinden oluşan bağımlı değişkenleri \%71 oranında açıklamaktadır.

$\mathrm{Bu}$ çalışmada birinci değişken çiftinin $\left(\mathrm{U}_{1-} \mathrm{V}_{1}\right)$ toplam varyansa en büyük katkıyı yaptığı görülmüş̧ür. Bu sonuçlar bağımlı ve bağımsız değişken setleri arasında önemli bir ilişkinin olduğunu ortaya koymaktadır. $\mathrm{X}$ değişken setindeki dışsal seyretme güdülerinden birinci $\mathrm{U}_{1}$ ve $\mathrm{V}_{1}$ kanonik değişkeni en çok açılayan orijinal değişken oyun bilgisi ( $\mathrm{x} 7$ ) olarak belirlenmiştir. $Y$ değişken setindeki içsel seyretme güdülerinden $U_{1}$ ve $V_{1}$ kanonik değişkeni en çok açıklayan değişken ise beceri düzeyi (y6), boyutlarıdır. Gencer vd. (2012) ise yaptıkları araştırmada en önemli değişken çiftlerinde şehir ve drama değişkenlerinin ön plana çıktığını vurgulamışlardır. $U_{2}$ ve $V_{2}$ değişken çifti için $X$ değişken setindeki dışsal seyretme güdülerinden ikinci kanonik değişkeni en çok açıklayan orijinal değişken popülarite (x2); Y değişken setindeki içsel seyretme güdülerinden ikinci kanonik değişkeni en çok açıklayan değişken taraftarlık (y4), değişkenleridir. Gencer vd. (2012) ise ikincil önemli değişken setlerinde oyuncular ve sosyal etkileşim değişkenlerinin öne çıktığını vurgulamışlardır. Yine Gencer vd. (2011) tarafindan basketbol seyircileri üzerine yapılan araştırmada estetik ve kaçış boyutlarının öne plana çıktığı vurgulanmıştır. İki aştırmadaki araştırma amaçlarının ve katılımcıların özelliklerinin birbirinden ayrı olması bu farklı sonucun ortaya çıkmasına etken olabilir. Nitekim Smith (2008) her spor türünün kendine özgü seyircisinin olabileceğini ve bu seyircilerin de güdülenme biçimlerinin birbirinden farklı faktörlerin etkisinde kalabileceğini belirtmiştir. Yine Smith'in (2008) de belirttiği gibi seyretme güdülerine ilişkin araştırmalar bilgilendirici etkiler yaratabiliyorken tüm araştırmaların da aynı sonucu vermediğini bilmek de önemlidir.

Yine sonuçlara göre seyircilerin spora ilişkin bilgi düzeyinin ve sporcuların yansıttığı sportif becerilerin diğer güdülerle etkileşimde daha önemli etkilerinin olduğu söylenebilir. Oyun bilgisi güdüsü spor branşını her yönüyle anlama, algılama, oyun kurallarını bilme ve oyun kuralları öğrenme gibi kavramları içermektedir. Bu araştırmada belirli bir takım taraftarına odaklanılmaması ve daha çok sporu seyretmeye iten sebepler üzerinde odaklanılması oyun bilgisi ve beceri gibi güdülerin ön plana çıkmış olabileceğini düşündürtmektedir. Çünkü özellikle ülkemizde futbol ve basketbol gibi branşlarda taraftalık olgusu ön plandayken diğer branşlarda daha çok oyuncular tarafindan sunulan gösteriyi anlamaya çalışan ve anladıkça da çeşitli özelliklere sahip görsel eğlence duygusunu yaşayan meraklı bir seyirci profili oluşabilmektedir. 
Polat, E. ve Yalçın, H.B. (2020). Spor seyircileri için dışsal ve içsel güdü ölçekleri kısa versiyon uyarlaması ve çok değişkenli ilişkisel bir uyarlama. Spor Bilimleri Araşstırmaları Dergisi, 5(1), 111-129.

\section{Öneriler}

$\mathrm{Bu}$ çalışmada elde edilen sonuçlar ışığında aşağıdaki öneriler dikkate alınabilir.

- SSİDÖ ve SSİ́GÖ farklı spor branşlarına özgü hazırlanarak kullanılabilir hale getirilmelidir.

- Konu bütünlüğünü sağlaması açısından spor seyretmede motivasyonsuzluk kaynaklarını ya da seyretme engellerini ortaya koyan bir ölçüm aracına da ihtiyaç vardır.

Yayın Etiği: Mevcut çalışmanın yazım sürecinde "Yükseköğretim Kurumları Bilimsel Araştırma ve Yayın Etiği Yönergesi” kapsamında bilimsel, etik ve alıntı kurallarına uyulmuş olup; toplanan veriler üzerinde herhangi bir tahrifat yapılmamış ve bu çalışma herhangi başka bir akademik yayın ortamına değerlendirme için gönderilmemiştir.

\section{KAYNAKLAR}

Alpar, R. (2010). Spor, sağlık ve eğitim bilimlerinden örneklerle uygulamalı istatistik ve geçerlik-güvenirlik. Ankara: Detay Yayıncılık.

Al-Thibiti, Y. (2004). A scale development for sport fan motivation. Doctorate Thesis, Florida: The Florida State University, College of Education, Department of Sport Management, Recreation Management and Physical Education.

Büyüköztürk, Ş. (2006). Sosyal bilimler için veri analizi el kitabı. 6. Baskı, Ankara: Pagem Yayıncılık.

Büyüköztürk, Ş., Kılıç Çakmak, E., Akgün, Ö.E., Karadeniz, Ş. ve Demirel F. (2017). Bilimsel araştırma yöntemleri. 23.Bask1, Ankara: Pagem Akademi.

Çokluk, Ö., Şekercioğlu, G. ve Büyüköztürk, Ş. (2010). Sosyal bilimler için çok değişkenli istatistik: SPSS ve LISREL uygulamalart. Ankara: Pegem.

Devellis, R.F. (1991). Scale development theory and applications. applied social research series V26. California: Sage Publications.

Eren, E. (2015). Örgütsel davranış ve yönetim psikolojisi. 15.Baskı, İstanbul: Beta Basım Yayım Dağıtım.

Eubank, R.L. \& Hsing, T. (2008). Canonical correlation for stochastic processes. Stochastic Processes and Their Applications, 118(9),1634-1661. https://doi.org/10.1016/j.spa.2007.10.006.

Funk, D. C. (2008). Consumer behavior in sport and events: Marketing action. Oxford: Elsevier.

Funk, D.C., Ridinger L.L. \& Moorman A.M. (2003). Understanding consumer support: Extending the Sport Interest Inventory (SII) to examine individual differences among women's professional sport consumers. Sport Management Review, 6, 1-32. https://doi.org/10.1016/S1441-3523(03)70051-5.

Gencer, R.T. (2015). Spectator motives and points of attachment: Gender differences in professional football. Anthropologist, 19(1), 77-85. https://doi.org/10.1080/09720073.2015.11891641.

Gencer, R.T., Kiremitçi, O., Aycan, A., Demiray, E. ve Unutmaz V. (2012). Profesyonel futbol takımı seyircilerinin spor tüketimine yönelik güdüleri ve bağlılık noktaları arasındaki ilişki. Ege Akademik Bakış, 12(Özel Sayı), 41-53.

Gencer, R.T., Kiremitçi, O. \& Boyacıŏlu, H. (2011). Spectator motives and points of attachment: An investigation on professional basketball. Journal of Human Kinetics, 30(2011), 189-196.

Gray, J.L. \& Starke, F.A. (1988). Organizational behavior: Concepts and applications. 4th Ed., New York, Macmillan Publishing Company. 
Polat, E. ve Yalçın, H.B. (2020). Spor seyircileri için dışsal ve içsel güdü ölçekleri kısa versiyon uyarlaması ve çok değişkenli ilişkisel bir uyarlama. Spor Bilimleri Araştırmaları Dergisi, 5(1), 111-129.

Harris, R.J. (2001). Canonical correlation. A primer of multvariate statistics. 3rd Ed. New Jersey: Lawrence Erlbaum.

James, J.D. \& Ross, S.D. (2004). Comparing sport consumer motivations across multiple sports. Sport Marketing Quarterly, 13(1), 17-25.

Jöreskog, K.G. \& Sörbom, D. (2001). Lisrel 8: Users reference guide. Chicago: Scientific Software International.

Kast, F. E. \& Rosenzweig, J. E. (1985). Organization and management: A systems and contingency approach. 4th. Ed. New York: McGraw-Hill International Edition.

Kline, P. (1994). An easy guide to factor analysis. New York: Routledge.

Mahony, D.F., Nakazawa, M., Funk, D.C., James, J.D. \& Gladden, J.D. (2002). Motivational factors influencing the behaviour of J. league spectators. Sports Management Review, 5(1), 1-24. https://doi.org/10.1016/S1441-3523(02)70059-4.

McDonald, M.A., Milne, G.R. \& Hong, J. (2002). Motivational factors for evaluating sport spectator and participant markets. Sport Marketing Quarterly, 11(2), 100-113.

Mullin, B. J., Hardy, S. \& Sutton, W. A. (2007). Sport marketing, 3th. Ed. Illinois: Human Kinetics.

Polat, E. \& Yalçın, H.B. (2014). External Motivations Scale for Sport Spectators (EMSSS) and Internal Motivations Scale for Sport Spectators (IMSSS) validity and reliability study. International Journal of Human Sciences, 11(1), 105-127.

Pons, F., Mourali, M. \& Nyeck, S. (2006). Consumer orientation toward sporting events: scale development and validation. Journal of Service Research, 8(3), 276-287. https://doi.org/10.1177/1094670505283931.

Pugh, R. C. \& Hu, Y. (1991). Use and interpretation of canonical correlation analysis in Journal of Educational Research articles: 1978-1989. Journal of Educational Research, 84(3), 147-152. https://doi.org/10.1080/00220671.1991.10886008.

Robbins, S.P. (1992). Essentials of organizational behaviour. 3rd Ed., New Jersey: Prentice Hall.

Rowan, N. \& Wulff, D. (2007). Using qualitative methods to inform scale development. The Qualitative Reports, $12(3), 450-466$.

Ryan, R. M. (1995). Psychological needs and the facilitation of integrative processes. Journal of Personality, 63(3), 397-427. https://doi.org/10.1111/j.1467-6494.1995.tb00501.x.

Ryan, R. M. \& Deci, E. L. (2000). Self-determination theory and the facilitation of intrinsic motivation, social development and well-being. American Psychologist, 55(1), 68-78. https://doi.org/10.1037/0003066X.55.1.68 .

Schermelleh-Engel, K., Moosbrugger, H. \& Müller, H. (2003). Evaluating the fit of structural equation models: Tests of significance and descriptive goodness-of-fit measures. Methods of psychological research online, 8(2), 23-74.

Schumacker, R. E. \& Lomax, R. G. (2004). A beginner's guide to structural equation modeling. 2nd. Ed. New York: Psychology Press.

Schwarz, E.C. \& Hunter, J.D. (2008). Advanced theory and practice in sport marketing. San Diego: Elsevier Inc.

Shank, M. D. (2005). Sport marketing: A strategic perspective. 3rd. Ed. New Jersey: Prentice Hall Inc.

Silah, M. (2000). Sosyal psikoloji (Davranış bilimi). Ankara: Gazi Kitabevi.

Smith, A.C.T. (2008). Introduction to sport marketing. Oxford: Elsevier Inc.

Sümer, N. (2000). Yapısal eşitlik modelleri: Temel kavramlar ve örnek uygulamalar. Türk Psikoloji Yazılarl, 3(6), 49-74. 
Polat, E. ve Yalçın, H.B. (2020). Spor seyircileri için dışsal ve içsel güdü ölçekleri kısa versiyon uyarlaması ve çok değişkenli ilişkisel bir uyarlama. Spor Bilimleri Araşstırmaları Dergisi, 5(1), 111-129.

Hair, J. F., Anderson, R. E., Tatham, R. L. \& Black, W. C. (1998). Multivariate data analysis. 5th. Ed. New Jersey: Prentice-Hall.

Trail, G.T. \& James, J.D. (2001). The motivation scale for sport consumption: Assessment of the scales psychometric properties. Journal of Sport Behavior, 24(1), 108-127.

Trail, G.T., Robinson, M., Dick, R. \& Gillintine, A. (2003). Motives and points of attachment: Fans versus spectators in intercollegiate athletics. Sport Marketing Quarterly, 12(4), 217-227.

Türkiye İstatistik Kurumu-TUIK. (2008). Spor istatistikleri-Sport statistics 2007. Ankara: Türkiye İstatistik Kurumu Matbaasi.

Wann, D.L. (1995). Preliminary validation of the sport fan motivation scale. Journal of Sport and Social Issues, 19, 377-396.

Yıldırım, A. ve Şimşek H. (2006). Sosyal bilimlerde nitel araştırma yöntemleri. 6. Baskı, Ankara: Seçkin Yayıncilik.

Yılmaz, V. ve Çelik, H. E. (2009). Lisrel ile yapısal eşitlik modellemesi-I: Temel kavramlar, uygulamalar, proglamlama. Ankara: Pegem Akademi.

Zhang, J.J., Lam, E.T.C., Bennett, G. \& Connaughton, D.P. (2003). Confirmatory factor analysis of the Spectator Decision-Making Inventory (SDMI). Measurement in Physical Education and Exercise Science 7(3), 5770. https://doi.org/10.1207/S15327841MPEE0702_1.

Bu eser Creative Commons Atıf-GayriTicari 4.0 Uluslararası Lisansı ile lisanslanmıştır. 